http://dx.doi.org/10.12775/szhf.2013.050

\author{
Anna Tomaszewska
}

\title{
Etyka Spinozy \\ a problem poznania transcendentalnego
}

Niejeden czytelnik Etyki, głównego dzieła Benedykta Spinozy, zapoznając się z filozoficznym systemem niderlandzkiego myśliciela, mógłby zapewne zastanawiać się nad tym, czy nie ma przypadkiem do czynienia z przedsięwzięciem niemożliwym. Pisany more geometrico traktat może się zrazu wydać systemem dogmatycznej metafizyki (by użyć określenia z filozoficznego słownika Immanuela Kanta), który - w intencjach autora - gdy tylko zostanie właściwie zrozumiany, powinien zostać przyjęty przez każdego, kto potrafi posługiwać się rozumem. Jednak wielu z tych, którym nie zarzucilibyśmy nieumiejętności posługiwania się zdolnością racjonalnego myślenia, odrzuci Spinozjańskie definicje i aksjomaty, stanowiące początek jego dedukcyjnych rozumowań. Czy traktat napisany „sposobem geometrycznym”, na wzór Elementów Euklidesa, miałby być niczym więcej jak tylko wyrazem subiektywnych intuicji i osobistego punktu widzenia swojego autora? ${ }^{1}$

\footnotetext{
${ }^{1} \mathrm{~W}$ ten właśnie sposób, jako osobiste przedsięwzięcie filozofującej jednostki, zdaje się odczytywać zamysł Spinozy J. Żelazna: „Spinoza wypowiada się we własnym imieniu, zdradza, jak sam rozumie znaczenia i związki pomiędzy znaczeniami pewnych pojęć albo jak nazwie określone zjawisko, ale nie orzeka, jak się rzeczy mają ani nie usiłuje - co w literaturze przedmiotu wydaje się najczęściej niedostrzegane - tworzyć systemu metafizycznego z pozycji ponadczasowego obserwatora, patrzącego na wszechświat zza boskiego ramienia. Jego dzieło przypomina raczej próbę skonstruowania modelu, w którym pewne hipotezy, tak jak je rozumie skończony umysł ludzki, mogłyby stanowić rodzaj racjonalizacji, pomocnej w zbu-
} 
Przyglądając się bliżej Etyce Spinozy, dostrzegamy kolejny problem. Otóż pierwsza jej część ustala definicje podstawowych terminów Spinozjańskiej metafizyki, wykazuje koekstensywność takich pojęć jak „przyczyna samego siebie”, „substancja” i „Bóg” oraz dowodzi jedyności Boga-substancji. Druga część traktuje o naturze człowieka, a dokładniej - duszy ludzkiej. Dowiadujemy się z niej m.in., że „istotę człowieka [...] stanowią pewne modi atrybutów Boga, mianowicie [...] modi myślenia”" z czego miałoby wynikać, że „dusza ludzka jest częścią nieskończonego rozumu Boga”3. Na mocy m.in. zasady paralelności porządku idei i porządku rzeczy okazuje się, że dusza jest złożoną ideą ludzkiego ciała. Człowiek jest skończonym, cielesno-duchowym modusem Boga-substancji - modusem, gdyż „do istoty człowieka nie należy byt substancji”" ${ }^{4}$ człowiek nie istnieje z konieczności własnej natury. Ale w jaki sposób - i tu pojawia się wspomniany problem - skończony modus substancji może tę ostatnią poznać? A przecież znaczną część Etyki zdaje się stanowić opis tego rodzaju poznania. Czy idea poznania substancji przez skończony podmiot ludzki jest wewnętrznie spójna? W takim bowiem poznaniu substancja, „to, co istnieje samo w sobie i pojmowane jest samo przez siebie”, miałaby być ujmowana przez modus, czyli „to, co jest w czymś innym, przez co też jest pojmowane" ${ }^{\prime}$. Pojęcie substancji jest logicznie pierwotne względem pojęcia jej modyfikacji. Tak więc aby poznać cokolwiek, trzeba już mieć pojęcie substancji. Ale na czym takie posiadanie pojęcia substancji, która okazuje się tożsama z Bogiem, miałoby polegać? Jakiego rodzaju wiedzę miałoby ono implikować? Skąd to pojęcie skończony umysł ludzki miałby zaczerpnąć?

Przeświadczenie, że mają do czynienia z przedsięwzięciem niemożliwym, może też niejednokrotnie towarzyszyć czytelnikom Krytyki czystego rozumu I. Kanta, dzieła, w którym skończony podmiot filozofujący odkrywa warunki możliwości oraz dokonuje zakreślenia granic własnego poznania. Przedsięwzięcie takie wymaga zajęcia pewnej szczególnej perspektywy teoretycznej,

dowaniu w miarę spójnego opisu natury”. J. Żelazna, Substancja jak światło? Wybrane pojęcia i problemy filozofii Spinozy, Wydawnictwo Naukowe Uniwersytetu Mikołaja Kopernika, Toruń 2010, s. 25-26.

${ }^{2}$ B. Spinoza, Etyka w porządku geometrycznym dowiedziona, tłum. I. Myślicki, oprac. L. Kołakowski, Wydawnictwo Naukowe PWN, Warszawa 2008, s. 78-79.

3 Tamże, s. 79.

${ }^{4}$ Tamże, s. 76.

${ }^{5}$ Tamże, s. 3.

${ }^{6}$ Tamże, s. 4. 
z której dobrze widać dziedzinę ukonstytuowaną przez relację poznawczą, „epistemiczne pole teorii”, by posłużyć się sformułowaniem polskiego kantysty Marka Siemka ${ }^{7}$. Zajmując tę perspektywę, filozofujący podmiot stawia się niejako poza badanym obszarem, na "granicy świata”, jak można powiedzieć, używając określenia z Traktatu Wittgensteina ${ }^{8}$. I podobnie jak oko nie należy do pola widzenia, które obejmuje, tak filozofujący podmiot, odkrywający warunki możliwości skończonego poznania ludzkiego, nie należy do opisywanej przez siebie dziedziny.

Problem poznania transcendentalnego nie jest jednakże li tylko problemem budzącej wątpliwości perspektywy poznawczej, lecz dotyczy również statusu tego poznania, rodzaju sądów, jakie się na nie składają. Tych, jak wiadomo, Kant wyróżnia trzy rodzaje: sądy analityczne, syntetyczne a posteriori oraz syntetyczne a priori. Do którego z nich zaliczają się sądy filozofii transcendentalnej? Przypomnijmy Kantowską definicję interesującego nas sposobu poznania: „Transcendentalnym nazywam wszelkie poznanie - pisze Kant we Wstępie do Krytyki czystego rozumu - które zajmuje się w ogóle nie tyle przedmiotami, ile naszym sposobem poznawania przedmiotów, o ile sposób ten ma być a priori możliwy. System takich pojęć nazywałby się filozofią transcendentalną"9. Poznanie transcendentalne bada możliwość apriorycznej wiedzy o przedmiotach, innymi słowy - stara się odpowiedzieć na pytanie: „W jaki sposób są możliwe syntetyczne sądy a priori?”"10.

W Metodologii transcendentalnej Kant twierdzi, że poznanie filozoficzne sprowadza się do analizy pojęć w przeciwieństwie do poznania matematycznego, które polega na konstrukcji obiektu w naoczności na podstawie posiadanego pojęcia, jest więc syntetyczne ${ }^{11}$. Jeśli zatem sądy dotyczące warunków możliwości sądów syntetycznych a priori miałyby status sądów ana-

${ }^{7}$ Zob. M. Siemek, Idea transcendentalizmu u Fichtego i Kanta. Studium z dziejów filozoficznej problematyki wiedzy, PWN, Warszawa 1977; tenże, Transcendentalizm jako stanowisko epistemologiczne, [w:] Dziedzictwo Kanta. Materiały z sesji kantowskiej, red. J. Garewicz, PWN, Warszawa 1976, s. 17-57.

${ }^{8}$ Por. L. Wittgenstein, Tractatus logico-philosophicus, tłum. B. Wolniewicz, Wydawnictwo Naukowe PWN, Warszawa 2002, s. 65 (teza 6.632).

9 I. Kant, Krytyka czystego rozumu, przeł. R. Ingarden, Wydawnictwo ANTYK, Kęty 2001, s. 68 (B 25).

10 Tamże, s. 64 (B 19).

11 „Poznanie filozoficzne jest poznaniem rozumowym [uzyskiwanym] na podstawie pojęć, matematyczne poznanie zaś poznaniem na podstawie konstrukcji pojęć. Skonstruować zaś pojęcie to znaczy przedstawić odpowiadającą mu naoczność a priori”. Tamże, s. 540 (A 713/B 741). 
litycznych, punktem wyjścia do ich sformułowania musiałoby być posiadane przez transcendentalnego filozofa pojęcie doświadczenia czy też poznania. Co więcej, sądy będące ich negacją musiałyby być wewnętrznie sprzecz$n^{12}$. Kant jednak twierdzi, że możemy bez sprzeczności pomyśleć poznanie inne niż nasze, np. poznanie istot wyposażonych w naoczność nie-zmysłową $^{13}$, a zatem negacja sądów mówiących o warunkach możliwości naszego doświadczenia nie prowadzi do sprzeczności. To oznacza, że nie mogą to być sądy analityczne. Nie mogą to być także sądy syntetyczne a posteriori, ponieważ wówczas poznanie dotyczące warunków poznania apriorycznego byłoby czymś w rodzaju empirycznej psychologii czy też „fizjologii umysłu ludzkiego"14 , której autorstwo przypisuje Kant Locke’owi i której - dodajmy zbytnio nie ceni. Pozostaje wobec tego tylko jedna możliwość - mianowicie, że poznanie transcendentalne ma charakter syntetyczny a priori $i^{15}$, a zatem sprowadza się do konstrukcji przedmiotu w czystej (nie-empirycznej) naoczności. Ale w takim razie czym różni się ono od poznania matematycznego?

Powiedzmy raz jeszcze, na czym polega problem poznania transcendentalnego u Kanta. Wyobraźmy sobie daną w konkretnym doświadczeniu parę zdarzeń, np. upadek porcelanowej filiżanki na podłogę i rozbicie się szkła na drobne kawałki. Zdarzenia te porządkuje relacja następstwa oraz związek przyczynowo-skutkowy: to właśnie pomyślenie o tych zdarzeniach jako powiązanych przyczynowo sprawia, że przedstawiamy sobie ich następstwo jako nieodwracalne. Czasowa i kauzalna struktura doświadczenia umożliwia percepcję i kategoryzację danych konkretnych zdarzeń, dlatego według Kanta struktura ta ma charakter aprioryczny, czyli konieczny i ściśle ogólny, obowiązujący dla każdego doświadczenia. Warunek poznania doświadczeniowego stanowią formy naoczności i kategorie intelektu, aprioryczna struktura doświadczenia mająca swoje źródło we władzach poznawczych podmiotu. Ale co umożliwia poznanie tej koniecznej struktury? Odpowiedź, że spra-

\footnotetext{
12 Por. tamże, s. 191 (A 151/B191).

${ }^{13}$ „Być może, że każda skończona istota myśląca musi się w tym koniecznie zgadzać z człowiekiem (choć tego nie możemy rozstrzygnąć). Mimo to ten sposób oglądania nie przestaje z powodu tej powszechnej ważności być przecież zmysłowością i to właśnie dlatego, że jest oglądaniem pochodnym (intuitus derivativus), a nie pierwotnym (intuitus originarius), a więc nie jest oglądaniem intelektualnym". Tamże, s. 97 (B 72).

${ }^{14}$ Tamże, s. 24 (A X).

${ }^{15}$ Argumenty za taką interpretacją statusu sądów filozofii transcendentalnej można znaleźć w: D. Pereboom, Kant on Justification in Transcendental Philosophy, Synthése, 1990, 85 (1), s. 25-54.
} 
wia to syntetyczny a priori charakter poznania naukowego, który struktura ta ma uzasadniać czy też umożliwiać, naraża nas na zarzut kolistości. Wobec tego - czy mamy tu do czynienia z pewnego rodzaju „wglądem” w aprioryczne warunki możliwości doświadczenia - czas, przestrzeń i czyste pojęcia intelektu - który można by porównać do intuicyjnego poznania Spinozjańskiej substancji?

Mówienie o szczególnego rodzaju intuicji czy też wglądzie warunkującym dostęp do treści pojęcia substancji (w przypadku Spinozy) i do apriorycznych struktur poznania empirycznego (w przypadku Kanta) wydaje się zrazu dość mylące, sugeruje bowiem, że poznanie oraz jego warunki można rozważać niezależnie od siebie. Takie podejście przypomina postępowanie Kartezjuszowego sceptyka, który zanim przystąpi do poznania czegokolwiek, usiłuje wypracować niezawodne kryterium wszelkiego poznania. Problem polega na tym, że wypracowanie owego kryterium oznacza już pewną aktywność poznawczą uwarunkowaną na rozmaite sposoby. Ale zarówno Spinoza, jak i Kant odrzucają kartezjańską metodę, nie rezygnując jednocześnie z idei podstaw wiedzy. Być może owe podstawy wiedzy są przez tych filozofów przyjmowane w punkcie wyjścia, jako pewne założenia, a potwierdzenie ich nieusuwalności ma zasadzać się - jak u Hegla - na skonstruowaniu ufundowanego na nich systemu wiedzy.

Z perspektywy Etyki skończone poznanie ludzkie jawi się jako pewien rodzaj modyfikacji substancji, jeden $z$ nieskończenie wielu rodzajów faktów należących do porządku natury ${ }^{16}$. Jednym ze znanych nam atrybutów substancji jest myślenie, na mocy zaś tw. $7, \mathrm{cz}$. $\mathrm{II}^{17}$ - wszystkim modi substancji

${ }^{16}$ Tę naturalistyczną tezę, zgodnie z którą umysł ludzki oraz wszystkie jego czynności i wytwory należą do porządku natury, potwierdzają stwierdzenia Spinozy, jakie znajdujemy w Przedmowie do trzeciej części Etyki: „Przyroda bowiem jest zawsze ta sama oraz jedna i ta sama jest wszędzie jej zdolność i moc działania, to znaczy prawa i zasady (leges et regulae) przyrody, według których wszystko się dzieje i z jednej formy zmienia się w drugą, są wszędzie i zawsze te same. Dlatego też jedną i tą samą musi być zasada (ratio) rozumienia natury wszelkich rzeczy, mianowicie przez powszechne prawa i reguły przyrody". B. Spinoza, Etyka, s. 141.

${ }^{17}$ Twierdzenie to brzmi następująco: „Porządek i związek idei jest taki sam jak porządek i związek rzeczy”. Tamże, s. 71. O tym, że chodzi o tożsamość między ideami a rzeczami na głębszym, ontologicznym, poziomie, a nie jedynie o rodzajową tożsamość struktur porządkujących idee i rzeczy, mówi przypis do cytowanego twierdzenia: „Dlatego też, czy pojmujemy przyrodę z punktu widzenia atrybutu rozciągłości, czy atrybutu myślenia, czy z punktu widzenia jakiegokolwiek innego atrybutu, odnajdziemy zawsze jeden i ten sam porządek, czyli jeden i ten sam związek przyczyn, to znaczy, że te same rzeczy po sobie następują" (kursywa moja - A. T.). Tamże, s. 72. 
rozpatrywanej z punktu widzenia atrybutu rozciągłości (rzeczom) odpowiadają modi substancji rozpatrywanej z punktu widzenia atrybutu myślenia (idee). Prowadzi to do tezy o całkowitej inteligibilności substancji. W istocie, rzecz i idea są jak awers i rewers jednej i tej samej monety. W klasycznej metafizyce - jej reprezentantem jest np. św. Tomasz z Akwinu - inteligibilność bytu polegała na jego relacji do umysłu poznającego ${ }^{18}$. W metafizyce Spinozjańskiej, choć każda rzecz w pewnym sensie ma umysł, ponieważ rozpatrywana jako modyfikacja atrybutu myślenia jest ona ideą, umysł zaś to nic innego jak idea danej rzeczy ${ }^{19}$, nie każda rzecz może być zdolna do poznania swojej natury. Zgodnie z aks. II, cz. II Etyki, to człowiekowi przysługuje myślenie ${ }^{20}$. Przyjmijmy, że chodzi tu o zdolność do refleksji, czyli tworzenia idei idei, uświadamiania sobie określonych treści przedmiotowych ${ }^{21}$. Zdolność ta pozostaje jednak własnością zaledwie niektórych zbiorów idei, a więc - zgodnie z zasadą paralelności - własnością pewnego rodzaju ciał. Warto podkreślić, że owe „zbiory idei” wiedzą, że ich poznanie obejmuje zaledwie wycinek pewnej całości. Być może jest tak dlatego, iż zdolność do refleksji zakłada także zdolność do ujęcia granic, czy może nawet ograniczeń jej przedmiotu, idea przedmiotu posiadającego granice ma zaś sens tylko niejako na tle idei przedmiotu nieograniczonego, takiego właśnie jak Spinozjański Bóg.

\footnotetext{
${ }^{18}$ Por. tzw. „wywód transcendentaliów” z art. 1 kw. 1 Quaestiones disputatae de veritate, gdzie czytamy np.: „Pierwsze porównanie bytu z intelektem wykazuje, że byt odpowiada [concordet] intelektowi - właśnie ta odpowiedniość nazywa się zrównaniem intelektu i rzeczy i w tym spełnia się formalnie natura prawdy”. Św. Tomasz z Akwinu, Kwestie dyskutowane o prawdzie, tłum. A. Aduszkiewicz i inni, t. 1, Wydawnictwo ANTYK, Kęty 1998, s. 17.

${ }^{19}$ „Przedmiotem idei, stanowiącej duszę ludzką, jest ciało, czyli pewien aktualnie istniejący modus rozciągłości, i nic innego”. B. Spinoza, Etyka, s. 81 (cz. II, tw. 13). Jednakże „to, co okazaliśmy do tej pory, jest bardzo ogólne i odnosi się do ludzi nie bardziej niż do innych jednostek, jako że wszystkie one są uduchowione, choć w różnym stopniu. W Bogu jest bowiem koniecznie idea każdej rzeczy, idea, której przyczyną jest Bóg, w ten sam sposób, jak idei ciała ludzkiego: dlatego też cokolwiek powiedzieliśmy o idei ciała ludzkiego [czyli o ludzkiej duszy resp. umyśle - przyp. A. T.], trzeba koniecznie powiedzieć o idei każdej rzeczy”. Tamże, s. 82 (cz. II, tw. 13, przypis).

${ }^{20}$ Aksjomat ten brzmi po prostu: „Człowiek myśli”. Tamże, s. 65.

${ }^{21}$ „Dusza ludzka poznaje nie tylko pobudzenia ciała, lecz i idee tych pobudzeń”. Tamże, s. 100 (cz. II, tw. 22). I dalej: „Dusza ludzka posiada wiedzę (cognoscit) o samej sobie o tyle tylko, o ile poznaje (percipit) idee pobudzeń ciała". Tamże (cz. II, tw. 23). Ludzki umysł zatem nie tylko „przedstawia sobą" pewne idee, ale jest także zdolny do przedstawiania idei tych idei, a więc do refleksji.
} 
Myśl, że idea tego, co nieskończone, Boga, warunkuje samopoznanie, sformułował Kartezjusz w Trzeciej Medytacji ${ }^{22}$. W niedokończonym Traktacie o poprawie rozumu Spinoza wypowiada podobną myśl. Mianowicie, rozważając problem wypracowania najlepszej metody poznania, autor Etyki stwierdza:

[N]ajdoskonalszą metodą będzie taka, która według normy danej nam idei Jestestwa najdoskonalszego wskaże, jak kierować umysłem. Łatwo stąd zrozumieć, w jaki sposób umysł, rozumiejąc coraz więcej, nabywa jednocześnie coraz nowsze narzędzia, z pomocą których łatwiej już postępuje w rozumieniu; albowiem [...] musi w nas istnieć przede wszystkim, jakoby narzędzie wrodzone, idea prawdziwa, przez zrozumienie której zostaje zarazem zrozumiana różnica, zachodząca pomiędzy takim poznaniem a wszelkim innym ${ }^{23}$.

A zatem Spinoza przyjmuje, że właściwe kierowanie umysłem wymaga posiadania pewnej normy czy też wzorca poznania, podobnie jak - można by powiedzieć - właściwe kierowanie działaniem wymaga posiadania wzorca człowieka etycznie doskonałego. Jak wynika z przytoczonych słów, geneza tego wzorca nie interesuje filozofa (nazywa on go jedynie ,jakoby narzędziem wrodzonym"), istotna bowiem pozostaje jego funkcja kierowania umysłem we właściwy sposób. Poznanie, obejmowanie refleksją coraz większego zakresu idei, pociąga za sobą doskonalenie się w posługiwaniu się metodą poznania i przybliża do realizacji zakładanego wzorca.

Tak więc dla Spinozy wzór poznania stanowi poznanie „z boskiego punktu widzenia", czyli takie, jakie miałaby istota, której nie byłyby właściwe żadne ograniczenia, i które obejmowałoby wszystko, co tylko może być poznane. Niekiedy zbliżamy się do tego rodzaju poznania: jest tak wtedy, gdy ujmujemy daną ideę intuicyjnie, czy też adekwatnie - jak wiadomo, scientia intuitiva

\footnotetext{
${ }^{22}$ We wspomnianym tekście Kartezjusz pisze: „pojmuję to zupełnie jasno, że więcej rzeczywistości jest w substancji nieskończonej niż w skończonej, i że zatem jest we mnie w jakiś sposób na pierwszym miejscu ujęcie tego, co nieskończone, przed ujęciem tego, co skończone, czyli ujęcie Boga przed ujęciem mnie samego". Dalej autor Medytacji tłumaczy, że to "ujęcie” nieskończonego Boga warunkuje ujęcie siebie samego jako istoty posiadającej rozmaite ograniczenia i braki. R. Descartes, Medytacje o pierwszej filozofii. Zarzuty uczonych mężów i odpowiedzi autora. Rozmowa z Burmanem, przeł. M. i K. Ajdukiewiczowie i inni, Wydawnictwo ANTYK, Kęty 2001, s. 66.

${ }^{23}$ B. Spinoza, Traktat o poprawie rozumu, [w:] tegoż, Traktaty, tłum. I. Halpern-Myślicki, Wydawnictwo ANTYK, Kęty 2003, s. 439.
} 
to według Spinozy najwyższy rodzaj poznania ${ }^{24}$. Jolanta Żelazna Spinozjańską intuicję charakteryzuje w następujący sposób:

Jednym z podstawowych warunków jej zaistnienia jest zdolność odnoszenia się [...] intelektu do jedności całego spektrum swoich możliwych przedmiotów i rozpoznanie przedmiotu jako pewnego aspektu takiej jedności ${ }^{25}$.

Poznanie intuicyjne polega zatem na ujmowaniu części w jej relacji do całości i zakłada (w jakimś sensie) poznanie całości. Słowami Leszka Kołakowskiego:

Z jednej strony jest ona [intuicja - przyp. A. T.], wcielona w ramy 'geometrycznej, kartezjańskiej wizji świata, analitycznym poznaniem rzeczy przez ich definicje [...]. Z drugiej strony jest całościowym oglądem przyrody przez pewien jej modus, jaki stanowi człowiek poznający. W intuicji, akcie czysto intelektualnym, wolnym od deformującego wpływu wyobraźni zmysłowej, dochodzi do skutku 'wiedza o jedności łączącej dusze z cała przyroda', to znaczy poznanie siebie nie jako części natury, ale jako identycznego z nią ontologicznie ${ }^{26}$.

Czy poznanie transcendentalne można porównać do Spinozjańskiego poznania „z boskiego punktu widzenia”? Bodaj wbrew intencjom autora Krytyki istnieją pewne przesłanki do (choćby częściowo) pozytywnej odpowiedzi na to pytanie. Zacznijmy od tego, że Kant jest przekonany o koniecznej prawdziwości twierdzeń dotyczących warunków możliwości doświadczenia (poznania empirycznego) i uniwersalności tych ostatnich; nie wątpi w to, iż odkryte przez niego formy naoczności zmysłowej i czyste pojęcia intelektu są takie, jakie opisuje Krytyka, a także, że jest ich właśnie tyle, ile Krytyka wyli$\mathrm{cza}^{27}$. Znamienne, że podczas gdy Newton określał przestrzeń jako sensorium

${ }^{24} \mathrm{O}$ wiedzy intuicyjnej czytamy w cz. II Etyki: „Prócz tych dwóch rodzajów wiedzy [z wyobrażeń i z pojęć - przyp. A. T.] jest jeszcze, jak dalej wykażę, trzeci, który nazywać będziemy 'wiedzą intuicyjną' (scientia intuitiva). Ten zaś rodzaj poznawania postępuje od adekwatnej idei formalnej istoty pewnych atrybutów Boga do wiedzy adekwatnej o istocie rzeczy". B. Spinoza, Etyka, s. 118. Wiedza intuicyjna jest „wiedzą o rzeczach jednostkowych” i „przewyższa [...] wiedzę uogólniającą (cognitio universalis)”. Tamże, s. 368.

${ }^{25}$ J. Żelazna, Substancja jak światło?, s. 163.

${ }^{26}$ L. Kołakowski, Jednostka i nieskończoność. Wolność i antynomie wolności w filozofii Spinozy, Wydawnictwo Naukowe PWN, Warszawa 2012, s. 152.

${ }^{27}$ Świadczy o tym m.in. takie oto stwierdzenie z jednego z przypisów do „Przedmowy do drugiego wydania”: „I ja też tylko jako hipotezę wysuwam w tej tu przedmowie ową przemianę 
Dei, Kant umieszcza ją „w” umyśle skończonego podmiotu poznającego, czyniąc ją subiektywną, ale konieczną formą zmysłowego doświadczenia. Sądy dotyczące warunków możliwości poznania empirycznego są czymś więcej niż hipotezami wyjaśniającymi taki, a nie inny charakter doświadczenia; nie wchodzą też raczej w skład rozumowań redukcyjnych, ponieważ rozumowania takie są zawodne, a składające się na nie sądy nie ustalają koniecznego związku między tym, co ma zostać wyjaśnione, a wyjaśnieniem. Natomiast Kantowskie sądy dotyczące form naoczności i kategorii intelektu ustalają właśnie konieczny związek między tymi ostatnimi a możliwością poznania.

Wróćmy do kwestii statusu sądów filozofii transcendentalnej. Jak wskazałam powyżej, nie mogą one być sądami analitycznymi ani sądami syntetycznymi a posteriori. Czy mogą to być wobec tego sądy syntetyczne a priori? Aby sąd miał charakter syntetyczny, a tym samym rozszerzał naszą wiedzę, nie może być uzasadniany jedynie na drodze analizy relacji między pojęciami podmiotu i orzecznika. Uzasadnienia takiego sądu musi dodatkowo dostarczać naoczność; jego niesprzeczność nie wystarcza do przypisania mu prawdziwości. Naoczność zaś jest bezpośrednim przedstawieniem jednostkowego przedmiotu ${ }^{28}$. Z jakim jednostkowym przedmiotem mielibyśmy do czynienia $\mathrm{w}$ przypadku poznania transcendentalnego? Czy przedmiotem tym mógłby być sam podmiot bądź jego umysł? Zważywszy na to, że warunkiem przedstawienia przedmiotu jednostkowego są według Kanta formy naoczności zmysłowej: przestrzeń i czas, te zaś mają swoje źródło w podmiotowej zdolności przedstawiania, trzeba by dojść do wniosku, iż podmiot musiałby zarazem podlegać warunkom poznania naocznego, jak i stanowić ich (nieuwarunkowane) źródło ${ }^{29}$. Można zaryzykować stwierdzenie - i jest

w sposobie myślenia, wyłożoną w Krytyce, a podobną do tamtej hipotezy. Czynię to jedynie, by zaznaczyć pierwsze próby takiej przemiany, które są zawsze hipotetyczne, jakkolwiek w samym mym dziele nie hipotetycznie, lecz apodyktycznie udowodnię ją na podstawie wyobrażeń czasu i przestrzeni i pierwotnych pojęć intelektu". I. Kant, Krytyka, s. 39 (B XXII, przypis; kursywa moja - A. T.). Sądy dotyczące warunków możliwości poznania empirycznego są więc czymś więcej niż hipotezami wyjaśniającymi; nie wchodzą one również w skład rozumowań redukcyjnych (zwanych w XX-wiecznej filozofii analitycznej wnioskowaniami transcendentalnymi), ponieważ rozumowania te są zawodne, a składające się na nie sądy nie ustalają koniecznego związku między tym, co ma zostać wyjaśnione, a wyjaśnieniem. Natomiast Kantowskie sądy dotyczące form naoczności i kategorii intelektu ustalają właśnie konieczny związek między tymi ostatnimi a doświadczeniem.

${ }^{28}$ Zob. I. Kant, Krytyka czystego rozumu, s. 73 (A 19/B 33), s. 306 (A 320/B 377).

${ }^{29}$ Taka interpretacja Kantowskiego podmiotu w pewnej mierze wychodzi naprzeciw interpretacji idealizmu transcendentalnego, mówiącej, że rozróżnienie na zjawisko i rzecz samą 
to druga część odpowiedzi na pytanie, czy poznanie transcendentalne ma coś wspólnego z poznaniem „z boskiego punktu widzenia” - że przypominałoby tym samym Spinozjańską substancję rozpatrywaną raz jako przyroda tworząca (natura naturans), innym razem zaś jako przyroda stworzona (natura naturata $)^{30}$.

Ale co właściwie umożliwia filozofującemu podmiotowi spojrzenie na poznanie $\mathrm{z}$ dwóch różnych perspektyw, o których wspominałam? Co umożliwia ujęcie poznającego podmiotu raz jako uwarunkowanego formami zmysłowej naoczności indywiduum, innym razem natomiast - jako nieuwarunkowanego źródła tych form? Czy zdolność do tego rodzaju poznania można wyjaśnić inaczej niż odwołując się do metafor mówiących o relacji między podmiotem boskim i ludzkim, do specyficznej intuicji relacji między tym, co uwarunkowane, a tym, co nieuwarunkowane? Dla Spinozy, w Traktacie o poprawie rozumu, możliwość poznania sub specie aeternitatis wydaje się zagwarantowana przez ideę ,Jestestwa najdoskonalszego" ${ }^{1}$, stanowiącą mia-

w sobie to w gruncie rzeczy rozróżnienie między dwiema perspektywami, z których można rozważać jedną i tę samą rzeczywistość. Zwolennikiem takiego odczytania idealizmu Kanta jest H. E. Allison (por. Kant's Transcendental Idealism. An Interpretation and Defense, Yale University Press, New Haven and London 2004). Konsekwencją interpretacji Allisona nie jest naturalistyczne ujęcie skończonego podmiotu poznającego, o jakim traktuje pierwsza Krytyka. Polemikę z interpretacjami naturalistycznymi można znaleźć w: H. E. Allison, On Naturalizing Kant's Transcendental Psychology, Dialectica, 1995, 49 (2-4), s. 335-356. Oczywiście interpretator Kanta i Spinozy, poszukujący w ich filozofii wątków wspólnych, może być skłonny uznawać za słuszne przynajmniej niektóre interpretacje transcendentalizmu w duchu naturalistycznym. Ale warto zwrócić uwagę na to, że naturalizm Spinozy bynajmniej nie musi być rozumiany $\mathrm{w}$ terminach redukcyjnego materializmu. Wiele zależy od tego, czy wyjaśniając Spinozjańskie pojęcie „Natury” położymy nacisk na jej aspekt materialny, czy też duchowy.

${ }^{30}$ Odróżniając te dwa sposoby rozważania przyrody, Spinoza wskazuje na identyczność między substancją i jej modyfikacjami - substancja i modi są w istocie tym samym, ale ujętym z perspektywy dwóch różnych podmiotów poznających. Wspomniane rozróżnienie Spinoza wyjaśnia w następujący sposób: „przez przyrodę tworzącą winniśmy rozumieć to, co jest samo w sobie i samo przez się daje się pojąć, czyli takie atrybuty substancji, które wyrażają istotę wieczną i nieskończoną, to znaczy [...] Boga, o ile rozważa się go jako przyczynę wolną. Natomiast przez [przyrodę] stworzoną rozumiem to wszystko, co wynika z konieczności natury Boga, czyli z każdego atrybutu Boga, to znaczy wszystkie modi atrybutów Boga, o ile rozważa się je jako rzeczy, które są w Bogu i które bez Boga nie mogą ani być, ani być pojęte”. B. Spinoza, Etyka, s. 43.

${ }^{31}$ Por. „W naturze rozumu leży, że poznaje rzeczy niejako pod postacią wieczności. [...] Albowiem w naturze rozumu leży, że rozważa rzeczy jako konieczne, a nie jako przypadkowe [...]. Tę zaś konieczność rzeczy poznaje [...] prawdziwie, tj. [...] taką, jaką jest sama w sobie. Otóż [...] ta konieczność rzeczy jest samą koniecznością wiecznej natury Boga. A zatem leży 
rę i normę poznania, oraz wypowiedziane w Etyce założenie o ontologicznej tożsamości między człowiekiem a naturą. Można powiedzieć, że tym, co Spinoza opisuje w Etyce, jest nie tyle poznanie substancji, Boga, przez skończony podmiot poznający, ile samopoznanie substancji w skończonym podmiocie. W przypadku Kanta nie ma jednoznacznej odpowiedzi na pytanie o możliwość poznania filozoficznego, zwanego poznaniem transcendentalnym. Można wprawdzie wskazać na zdolność czy też tendencję rozumu do wykraczania poza to, co uwarunkowane ku jego ostatecznym warunkom. Samej tej zdolności czy też skłonności nie da się jednak w satysfakcjonujący sposób wyjaśnić3 ${ }^{32}$. Musimy zatem poprzestać na konstatacji, że Kantowska filozofia transcendentalna albo nie daje odpowiedzi na pytanie o warunki możliwości wszelkiego poznania (pomija bowiem warunki poznania transcendentalnego), albo nawet jeśli takiej odpowiedzi udziela, to sama nie ma charakteru rzetelnej wiedzy.

\section{Bibliografia}

Allison H. E., Kant's Transcendental Idealism. An Interpretation and Defense, Yale University Press, New Haven and London 2004.

w naturze rozumu, że rozważa rzeczy pod tą postacią wieczności”. B. Spinoza, Etyka, s. 124. Sformułowanie Spinozy nie jest całkowicie jasne i wydaje się, że można je rozumieć przynajmniej na dwa sposoby: (1) poznawać coś pod postacią wieczności oznacza poznawać coś jako konieczne, a zatem jako tkwiące immanentnie w naturze Boga - takie poznanie jest zatem, choćby częściowym, poznaniem Boga; (2) poznawać coś pod postacią wieczności oznacza poznawać coś tak, jak poznaje je Bóg, czyli jako konieczne, zdeterminowane przez własną naturę.

${ }^{32}$ Można wprawdzie powiedzieć, że skłonność ta jest naturalna dla ludzkiego rozumu, ale wtedy trzeba by wyjaśnić, co właściwie ma się przez to na myśli. Czy stwierdzenie to należy rozumieć jako należące do antropologii czy może raczej do czegoś, co można by nazwać metafizyką rozumu (nauką zajmującą się odpowiedzią na pytanie „czym jest rozum jako taki?”)? Krytyka czystego rozumu nie dostarcza jednoznacznej odpowiedzi. Kant przyjmuje po prostu, że „metafizyka, choć nie jako nauka, to jednak jako wrodzona skłonność (metaphysica naturalis) istnieje rzeczywiście. Albowiem rozum ludzki powodowany własną potrzebą, a nie tylko samą próżnością posiadania wielu wiadomości, zmierza niepowstrzymanie do tego rodzaju pytań, na które nie można odpowiedzieć przez stosowanie rozumu w obrębie doświadczenia ani przy pomocy zapożyczonych odeń zasad. Tak też u każdego, w kim tylko rozum wzniósł się do spekulacji, istniała rzeczywiście zawsze jakaś metafizyka i zawsze w nim też istnieć będzie”. I. Kant, Krytyka, s. 65 (B 21). 
Allison H. E., On Naturalizing Kant's Transcendental Psychology, Dialectica, 1995, 49 (2-4).

Descartes R., Medytacje o pierwszej filozofi. Zarzuty uczonych mężów i odpowiedzi autora. Rozmowa $z$ Burmanem, tłum. M. i K. Ajdukiewiczowie i inni, Wydawnictwo ANTYK, Kęty 2001.

Kant I., Krytyka czystego rozumu, tłum. R. Ingarden, Wydawnictwo ANTYK, Kęty 2001.

Kołakowski L., Jednostka i nieskończoność. Wolność i antynomie wolności w filozofii Spinozy, Wydawnictwo Naukowe PWN, Warszawa 2012.

Pereboom D., Kant on Justification in Transcendental Philosophy, Synthése, 1990, 85 (1).

Siemek M., Idea transcendentalizmu u Fichtego i Kanta. Studium z dziejów filozoficznej problematyki wiedzy, PWN, Warszawa 1977.

Siemek M., Transcendentalizm jako stanowisko epistemologiczne, [w:] J. Garewicz (red.), Dziedzictwo Kanta. Materialy z sesji kantowskiej, PWN, Warszawa 1976.

Spinoza B., Etyka w porządku geometrycznym dowiedziona, przeł. I. Myślicki, oprac. L. Kołakowski, Wydawnictwo Naukowe PWN, Warszawa 2008.

Spinoza B., Traktat o poprawie rozumu, [w:] tegoż, Traktaty, tłum. I. Halpern-Myślicki, Wydawnictwo ANTYK, Kęty 2003.

Tomasz z Akwinu, Kwestie dyskutowane o prawdzie, tłum. A. Aduszkiewicz i inni, t. 1, Wydawnictwo ANTYK, Kęty 1998.

Wittgenstein L., Tractatus logico-philosophicus, tłum. B. Wolniewicz, Wydawnictwo Naukowe PWN, Warszawa 2002.

Żelazna J., Substancja jak światto? Wybrane pojęcia i problemy filozofii Spinozy, Wydawnictwo Naukowe Uniwersytetu Mikołaja Kopernika, Torun 2010.

\section{Abstract \\ Spinoza's Ethics and the Problem of Transcendental Cognition}

The article makes an attempt at comparing two perspectives from which philosophical cognition starts - a perspective which can be encountered in Spinoza's Ethics and a perspective which can be encountered in Kant's Critique of Pure Reason. In the first case, a finite subject of the philosophical cognition embarks on the cognition of the substance (Nature, God), that is, reality in its comprehensiveness; in the second case, a finite subject of philosophical cognition reflects upon the totality of the field of possible experience (empirical cognition), uncovering the conditions of its possibility. Both kinds of cognition consist in a pursuit to comprehend what is necessary and strictly universal. I claim that as much as the source of the cognition 
at stake is, on Spinoza's account, provided by the intuitive grasp of the ontological identity of the subject and the whole of the reality (substance, Nature, God), on Kant account, indicating the source or the ground of the transcendental cognition proves more difficult (if not impossible), even though it might be granted that as in Spinoza's cognition of the substance, also in the cognition which furnishes the judgments of the Critique of Pure Reason, intuition plays the decisive role.

Key words: Spinoza, Kant, transcendental cognition, intuition, necessity, mind 